and has selected additional plates from the modern period and contributed commentary upon developments following 1924.

It should be pointed out that neither Morison's nor Day's contributions to the text are purely historical in approach. Both men concern themselves at length with the esthetic of typographic usage, and the resulting essays are really lectures in the philosophy of the typographic art. This philosophy is then made graphic by the many fine plates.

Almost anyone who claims to be an expert in a field reserves the right to argue with another expert's selection of illustrative material, and some will no doubt feel that other pages than those shown in The Typographic Book could better manifest the development of type employment over five centuries. This reviewer's estimate, however, is that the number who will choose to carp at the present selection will be minimal. In the first place, the unanimously accepted "landmarks" are all represented; in the second place the authors have not let personal prejudices or special interests override their sound and balanced judgment; and in the third place their selection from among the lesser known, breadand-butter works is based upon vast experience and a good eye for typographic beauty.

The book is nicely designed and beautifully printed on fine paper. The facsimiles are excellently reproduced, and the volume comes stoutly boxed. All-told, The Typographic Book succeeds very well.-D.K.

\section{Planning Library Buildings for Service. Proceedings of a Library Buildings and Equipment Institute, July 6-8, 1961.} Ed. by Harold L. Roth. Chicago: ALA, 1964. 128p. \$3.75. (64-17057).

College and university librarians who lament the passing of the ACRL buildings institutes of pre-reorganization days and who miss the ACRL monographs that recorded the workings of these institutes can take some comfort in the appearance of yet another volume of proceedings of the postreorganization institutes sponsored by the Library Administration Division's section on buildings and equipment. Whether the larger scope of the new series of institutes benefits academic librarians or not is less important than whether the volume at hand records a well planned institute and is itself interesting, informative, and well edited. Planning Library Buildings for Service meets most of these requirements even though in many places the text bears little relation to the title.

Not quite half of this volume's 127 pages are given over to two panel discussions and six general papers of unusual quality. The remaining pages present, in three sections, the plans of six college and university libraries, four public libraries, and six school libraries. Building plans, good and bad, are always worth studying, and those offered here are no exception to the rule, but it is the opening section of general papers that lends this publication its distinction.

The first paper, "Elements in Planning a Library Building Program," by Ralph Ellsworth, is the blend of sage advice and restless inquiry that we have come to expect from one of our most experienced building consultants and most persistent visionaries. Ellsworth's abiding virtue is that he is never satisfied. Here he delivers up his elements of the building program not as rigid tenets but as imperfect judgments that are subject to whatever changes the "technology of learning" demands.

Following the Ellsworth paper are two dealing with library furniture: "Judging Value When Purchasing Wood Library Equipment," by Rudolph Willard and "Wood, Metal, or Plastic Equipment," by Donald Bean. It is never an easy task to follow Ralph Ellsworth, but if these papers seem mundane by contrast it is less the fault of the writers than of the subjects with which they have to deal. Though neither paper presents much that is new, each offers information that the inexperienced librarian will find useful in dealing with certain kinds of salesmen and purchasing agents.

The next two papers are by architects, and both are first-rate. Stanley James Goldstein's essay on "Environmental Control" might seem elementary to another architect, but to most librarians it will seem wise and profound beyond belief. Here is an architect who knows what a library building should be and who furthermore knows that very few of our buildings measure up to 
our expectations. But Goldstein knows still more. He knows why our buildings so often fail. He blames not the buildings themselves but the faulty plumbing, heating, ventilating, air-conditioning, and electrical systems our buildings provide. The burden of his complaint, therefore, has to do with the quality of engineering, but he does not seek to absolve the architect of responsibility. On the contrary, he points out that "mechanical and electrical services have represented, traditionally, the areas of least interest and smallest degree of comprehension by architects." It is not accidental, therefore, that, in his words, "these mechanical and electrical services represent the major areas of consumer contact, comfort, and criticism." Goldstein concludes with a plea for liaison between architects and librarians through the medium of their respective organizations, the American Institute of Architects and the ALA buildings institutes. Whether we librarians have heeded this good advice is not clear, but perhaps the invitation is still open. The August 1964 Institute for the Training of Library Building Consultants that brought a number of librarians and architects together at Boulder, Colorado, was one step in the right direction.

The soundness of including architects in the programs of our buildings institutes is further demonstrated by Francis J. McCarthy's contribution. Entitled "Human Mechanics in Relation to Equipment" McCarthy illustrates by text and sketches many of the space requirements of the human body in a wide variety of postures assumed by library patrons. Here are readers standing, kneeling, squatting, bending, sitting, and sprawling as they (and we) are apt to do as they peruse shelves, sit in chairs, or read at tables. How far people can reach and how far they can see receive equal attention, as do the varying requirements of readers of various ages. All of these measurements were taken not for their own sake, but as the means of testing many of our cherished standards, such as the length of shelves, the height of ranges, the width of aisles, and the arrangement of card catalog cases. Many of our assumptions McCarthy found wanting and, while some of us may not accept his alternatives, we can all admire the searching spirit of his investiga- tion and apply his attitude of skepticism to most of the equipment with which we surround and sometimes barricade ourselves.

In contrast to the detailed and specific papers of architects Goldstein and McCarthy, the panel discussion entitled "Involving Others in Planning" seems almost impromptu. Chaired by Ralph Esterquest, who provides a graceful introduction to the subject, the discussion is taken up in turn by William Chait for the public library, by John Nicholson for the academic library, by Virginia McJenkin for the school library, and by Alfred Brandon for the special library. In each of these presentations and in the general discussion that follows a number of interesting points are made, but on balance the performance tends to illustrate the difficulty of finding common ground for librarians from different types of libraries and to bear out Ralph Ellsworth's opening salvo: "Libraries, like people, do have elements in common, but their differences are more significant than their similarities."

Section one of the Proceedings concludes with two pieces of limited interest to college and university libraries. "Bold, New Steps in Education," by Frank J. Woerdehoff attempts to suggest what the schools of tomorrow can and will be and what place the school library, destined to become "a learning resource center," will occupy in the scheme of things. Finally, a panel discussion on "The Place of the School Library Facilities in the New Curriculum" offers the views of Margaret Moss, chairman; Ian Ironside, architect; Kenneth I. Taylor, Jean Crabtree, and Leonella M. Jameson, school librarians. In view of the ideas of these enthusiastic panelists, it may be appropriate to quote once again from Ellsworth's opening paper.

"Those of you who have seen the Trump Report or who have read the reports of the Educational Facilities Laboratories, Inc., will realize the magnitude of the ideas that are fermenting in elementary and secondary school building planning. To be sure, the schools are at least two decades behind the colleges and universities; but that is to be expected, because schools have been run by trained experts and colleges and universities by educated amateurs. The 
point is that if the lower schools ever do put into practice some of the new ideas, the graduates of these schools will come to college with learning equipment that will force us to raise our library sights many notches."

Beyond listing the libraries whose building plans are presented and discussed in Section Two little more need be said about this publication. For the most part the plans speak for themselves more eloquently than do the critics. They would speak even more clearly if dimensions were consistently given or, at the very least, a scale were provided for each plan. In addition to four public and six school libraries, the lineup of college buildings is as follows: University of Pittsburgh library; Alma College library, Alma, Mich.; University of Alberta library; John Carroll University library, University
Heights, Ohio; Newark Colleges of Rutgers University library; and Oregon State University library, Corvallis.-John P. McDonald, University of Connecticut.

\section{COLLECTION SYSTEM}

(Continued from page 120)

nomically, as well as efficiently, their circulation services. Because of the lack of the need for elaborate systems engineering and the relatively low cost of the library-based equipment, this is a system worthy of a closer look from those libraries which have access to a computer, are spending $\$ 2,500$ or more on circulation procedures, and which have a minimum number of circulation points.

\section{Preconference Library Buildings Institute}

The Library Administration Division Preconference Library Buildings Institute is scheduled for July 1-3 and will be held at the Sheraton-Cadillac Hotel, Detroit, Michigan. The registration fee of $\$ 12.00$ should be sent to the LAD office at ALA headquarters.

The institute will consist of an opening general session, which will be devoted to a discussion of mistakes that have been made in recent library buildings, and five meetings for each of the three types of libraries-public libraries, school libraries, and college and university libraries.

The LAD Architecture Committee for Public Libraries, in cooperation with the American Library Trustees Association, will devote two of its meetings to the role of the trustee in library planning and two other meetings to the presentation and critiques of public library plans. The Resources and Technical Services Division will cooperate in the presentation of a final session which will consider the planning of a technical processing area in a large public library.

The Buildings Committee for College and University Libraries will devote four of its meetings to the presentation and critiques of plans of junior college, college, and university libraries. The final session will be devoted to the planning of a technical processing area in a large university library.

"The Planning School Library Quarters Committee is arranging sessions on "Team Planning the School Library"; "Planning a Central Office Processing Center"; "Novel and Ingenious School Libraries"; and "Accommodating Non-print Materials and Equipment in School Library Quarters." Their last session will consist of a tour to a selected number of school libraries in the Detroit area. 